\title{
E-TOURISM SERVICES IN POLISH TOURISTS' OPINIONS
}

\author{
Joanna Papińska-Kacperek \\ University of Lodz, Poland \\ E-mail: jpapkac@pocztawz.uni.lodz.pl
}

\begin{abstract}
E-tourism is most often related only with web pages of travel agencies or aggregators offering many services, where it is possible to make transactions electronically. Whereas many applications and devices are applied in tourism, like the audio guides and mobile guides (sometimes with augmented reality functions), electronic cards in museums, $2 D$ codes systems, web pages for individual tourists, geographic information systems (e.g. Google Street View), social network sites recommendation, and profiles of cities on social networks sites like Facebook. Polish tourists'opinions about mentioned innovative tools will be presented as the report from the survey conducted among students and graduates from three Polish universities. The objectives of the study are: investigating the popularity of e-tourist services in Poland and verifying whether municipal authorities promote e-tourism initiatives.
\end{abstract}

Key words: e-tourism, mobile guide, audio guide, QR code.

\section{Introduction}

In the information society information management supported by ICT tools is the crucial factor of the industry and services (Papińska-Kacperek, 2008). Computer systems appeared in many areas of life like communication, work, commerce, banking as well as administration and tourism. The internet became the indispensable communication channel. The Internet and other ICTs increased the number of choice for consumers: choice for searching and purchasing on the Internet. New technologies, new digital products and services have emerged. Many electronic services like e-commerce or e-banking have replaced humans travel with information flow. New media, access technologies, web applications and mobile technologies have developed.

\section{Problem of Research}

The World Tourism Organisation (UNWTO) defines tourism as a social, cultural and economic phenomenon, which entails the movement of people to places or counties outside their usual environment for personal or professional purposes. Tourism comprises the activities of people who travel and stay for leisure, business or for other aims, no longer than a year without a break, outside of everyday surroundings, with exception to all trips which the main goals are: the gainful activity or active recreation outside place of residence.

Tourism is a field based heavily on the exchange of information. The main activities of travel arrangements are: drive to the destination, accommodation, knowledge about the structure of local transport, location of catering points, worth seeing facilities (including opening hours, ticket prices, etc.), selection of objects, the optimal order of sightseeing, return to the place of residence, and now also the map with access points from which the Internet is available. It is important because nowadays many travellers use the Internet and people very often use mobile phones and smartphones allowing connection to the Internet in these locations for free.

Today the Internet is the major source of tourist information for travellers. According to the W3C in 2005, $95 \%$ of Internet users used the Internet for searching travel related information (Cech, Bures, 2009). Mobile devices equipped with GPS and enhanced with multimedia 
Joanna PAPIŃSKA-KACPEREK. E-Tourism Services in Polish Tourists' Opinions

PROBLEMS

OF MANAGEMENT

IN THE $21^{\text {st }}$ CENTURY Volume 7, 2013

34

features together with decreasing mobile data prices have resulted in larger usage of mobile services. Mobile phone with camera allows for fast visiting web pages through reading $2 \mathrm{D}$ codes more and more frequently printed on promotion materials. Currently, 2D barcodes are applied not only on promotional materials in newspapers or street advertising, but are also used in Tourist Information Systems - where placed on crucial objects. Such an arrangement allows to get information about those objects quickly. The first Polish example is the project "Decode Łódź” (In Polish "Odkoduj Łódź”).

There are many web pages prepared for mobile devices or mobile applications mostly dedicated to iOS or Android, commercial or free. In both cases they can be downloaded from online stores: Apple Store and Android Market. In many cities it is possible to rent the phone, if the visitor does not have one. Currently, there are many mobile tourist guides, offering a number of the diverse functionalities. Another example of these applications are audio guides: applications, or MP3 files, which can be used on many devices, and extends the group of the recipients.

Mobile devices like mobile phone or smart card allow using of a new method of paying comfortably and handy when sightseeing. New solutions adapt NFC technology (Near field Communication). A smart card entitling to travel by public transport and visiting the major sights is often dedicated for tourists. But NFC is used not only in payment and ticketing but also to tag objects. Visitors can access additional information about museum exhibitions at NFC tags. Such systems were tested in 2011 in two museums in London (Pesonen, Horster, 2012, p. 15) and in 2012 in Kraków (Gontar, Papińska-Kacperek, 2012). The augmented reality systems are increasingly being an element of mobile applications for smartphones. They combine realworld images (picture taken with the camera phone) with virtual elements, which are complementary to the real world with additional information and promotional items.

Mobile application or semantic tool can help to optimise the trip: it can determine the best sequence of sightseeing objects chosen by a tourist. To develop such tools the suitable resources are necessary. Pages of tourist information can be a source for semantic web search engines or agents to help plan excursion. Intelligent Travel Planning is a distributed multi-agent system that solves the problems involved in planning the trip (Cech, Bures, 2009). Question - if there are pages already applying the standards to facilitate proper operation of these programs?

E-tourism is the application of ICTs on the tourism industry (Buhalis, Jun, 2011). They suggested that e-tourism reflects the digitisation of all processes and value chains in travel, hospitality and catering industries. That includes ICTs applied for maximising the efficiency and effectiveness of the tourism as the organisation. E-tourism revolutionises all business processes, the entire value chain as well as the strategic relationships of tourism organisations with all their stakeholders. However, it is not only the sale of travel services via the Web. Buhalis in 2008 admitted that e-tourism has three main areas: consumers and demand dimension, technological innovations and industry functions. It takes advantage of reorganising all processes.

Electronic tourism was often related only to the web pages of travel agencies or aggregators offering many services, whereas many applications and devices are applied in tourism. There are: the audio guides and mobile guides (sometimes with augmented reality functions), the electronic cards in museums, 2D codes systems, web pages for individual tourist, geographic information systems (such as Google Street View), the social network sites recommendation, and profiles of cities on the social network sites like Facebook. Therefore e-tourism, means the use of ICT in all processes related to tourism, i.e. tourist activity, promotion of the tourist products, cash flow resulting from the sale of these services, sightseeing and getting around travel destinations (Gontar, Papińska-Kacperek, 2012, Papińska-Kacperek 2013).

Tourism as an economy field has a significant impact on various areas of social life and economic development. According to preliminary estimates of the Polish Institute of Tourism in 2011, Poland attracted 13.3 million tourists. It is a rise of 7\% in relation to 2010 . It is estimated that e-tourism will constitute about $40 \%$ of the turnover of the worldwide tourism industry. The tourism is perceived as a promising industry in Poland. 
E-tourism is not included in the basket of 20 e-services selected by the EU to assess e-government development. But it does not mean that it is not an important factor in local government. Tourists can find the required data on the existing social tourist information systems such as WikiTravel, Wikitude World Browser. However, the most recent information should be published on the sites created by the local administration, which should make every single effort to help tourists in the region. Information about new innovative solutions for getting around and visiting can attract to the region.

\section{Research Focus}

There are many described cases of ICT tools on the supply side of the tourism market (eTourism Case Studies 2008). The purpose of this study is to examine the ICT usage on the demand side in Poland. Web pages' review of Polish Euro 2012 host cities and 2 additional cities confirmed in 2012, that it was possible to find a lot of the helpful information needed for tourists, such as maps and brochures to download and print (Gontar, Papińska-Kacperek, 2012). There were the databases of accommodation, objects to visit in the city and region, restaurants, cultural events and tourist routes. On all analysed web sites, there was basic information on tourism, in at least two foreign languages. In the era of widespread use of mobile devices with Internet access, it was surprising that only three analyzed pages had a mobile version. It was also astonishing that many mobile applications prepared or supported by the local government were dedicated only for certain types of mobile phones. Not all initiatives related to e-tourism, such as mobile guides and audio guides were described in, or accessible from the city pages. This is not surprising in the case of commercial applications, but several not mentioned innovations were supported by the city councils (m-guides).

The content of web sites is changing and today similar review would give certainly better result. But this time the author decided to examine whether Polish individual tourist enjoys the services of e-tourism, or if he or she looks for information on the web sites of the local authorities. According to estimates of the Institute of Tourism, in 2012, the Polish tourists took part in the 40.5 million domestic trips, an increase of $31 \%$ more than in 2011 (TNS 2013). Thus, a large number of users should be interested in acquiring information related to travel and accommodation on the Internet, and the use of innovative features supporting sightseeing.

\section{Methodology of Research}

In order to obtain the study participants, the invitation with link to Web survey was sent in e-mail to students and university graduates from 3 Polish universities of Łódź, Poznań and Szczecin. Respondents were also encouraged to invite their colleagues or acquaintances to visit this link. Therefore sample of research was collected by non-probability method: purposive sampling (students as a young and very often travelling people are perceived to be an appropriate respondents) and snowball sampling (respondent is asked to identify another potential respondent). The survey was active at the turn of May and June 2013.

The survey was completed by 186 respondents. Women constituted $67 \%$ of them. Age ranged from 19 to 50 but $77 \%$ of respondents were $19-25$ years old. $27 \%$ of participants were MA degree holders, $31 \%$ bachelor's degree holders and $42 \%$ were postgraduates.

Most of the questions were closed, but many provided the opportunity to add the own responses, such as examples of sites with train schedules, pages with information for tourists and examples of sites where is possible to enjoy the audio-guide.

Different techniques of statistical analysis were used. The collected data are summarised quantitatively, also measured the strength of association between demographic characteristics and selected behaviour of respondents. The C- Pearson's contingency coefficient was calculated. 
PROBLEMS

OF MANAGEMENT

IN THE $21^{\text {st }}$ CENTURY

Volume 7, 2013

\section{Results of Research}

The study results showed that $90 \%$ of respondents check train or bus schedules on the website but only $47 \%$ buy a ticket on the Internet. Only $7 \%$ pooled looking for accommodation without the use of the Internet. $26 \%$ never reserved room via the Internet. Majority checks the location of the facilities planned to see on the visited city, $61 \%$ on the sites of the municipal authorities. The majority of respondents checked the way of reaching a planned destination on Google Maps (85\%) or at city sites hosted by municipal authorities (35\%). $70 \%$ of respondents looked for photographs of the planned destination points, $55 \%$ on Google Street View.

Only $36 \%$ don't use a mobile phone during the trip. For others mobile phone helps in locating objects by GPS (54\%) and checking the opening hours of museums, restaurants (46\%). Only $16 \%$ read QR codes, $12 \%$ use mobile guide and $11 \%$ use mobile in locating objects with augmented reality application. Detailed data in combination with the age of respondents are shown in Table 1.

Table 1. Objectives of mobile phone use during travel.

\begin{tabular}{|c|c|c|c|c|c|c|}
\hline \multirow{2}{*}{ Objective } & \multicolumn{5}{|l|}{ Age } & \multirow{2}{*}{ Total } \\
\hline & $19-22$ & 23-25 & $26-30$ & $31-40$ & $41-50$ & \\
\hline I do not use my phone & 11 & 14 & 4 & 1 & 1 & 31 \\
\hline In anything related to tourism & 21 & 15 & 4 & 1 & 2 & 43 \\
\hline In reading $Q R$ codes & 11 & 10 & 6 & 1 & 1 & 29 \\
\hline In playing downloaded audio guides & 2 & 2 & 1 & 1 & 0 & 6 \\
\hline In locating objects using augmented reality application & 9 & 6 & 6 & 0 & 0 & 21 \\
\hline In locating objects by GPS location & 34 & 41 & 22 & 3 & 1 & 101 \\
\hline $\begin{array}{l}\text { In checking the opening hours of museums, restau- } \\
\text { rants }\end{array}$ & 34 & 32 & 17 & 1 & 1 & 85 \\
\hline
\end{tabular}

Table 2. Source of information useful for tourists (\%).

\begin{tabular}{lll}
\hline Source of information & Many answers possible & One best answer \\
\hline The local website such as Krakow Our Town & 60.22 & 38.17 \\
\hline The city profile on a social network & 38.71 & 18.82 \\
\hline Other & 15.05 & 13.98 \\
\hline The website of local authorities & 44.62 & 11.83 \\
\hline Traditionally, without electronic media & 20.4 & 9.68 \\
\hline The mobile application (m-Guide) & 5.91 & 7.53 \\
\hline Total & & $100 \%$ \\
\hline
\end{tabular}


The respondents are mostly looking for information about interesting objects on the web sites prepared by local newspapers or local organisations $(60.22 \%)$, local authorities (45\%) or social networks (39\%). And the best in their opinion is local web site $(38.17 \%)$, but not prepared by authorities (Table 2). Only 16\% of the respondents visited the city where a tourist card allowed a ride on public transportation and tours of selected objects.

There was calculated the C-Pearson's contingency coefficient measured relationships between demographic features and accommodation booking, transportation and the best source of tourist information. As can be seen from Table 3, the demographic characteristics of the study population have a much greater impact on the assessment of the sources of information and the purpose of using mobile phones while travelling.

Table 3. Pearson's contingency coefficient.

\begin{tabular}{lllll}
\hline Demographic features & The best source & $\begin{array}{l}\text { Purpose } \\
\text { of mobile phone use }\end{array}$ & $\begin{array}{l}\text { Transportation } \\
\text { booking } \\
\text { on the web }\end{array}$ & $\begin{array}{l}\text { Accommodation } \\
\text { booking } \\
\text { on the web }\end{array}$ \\
\hline Age & 0.39 & 0.26 & 0.19 & 0.17 \\
\hline Sex & 0.22 & 0.39 & 0.15 & 0.05 \\
\hline Education level & 0.25 & 0.26 & 0.09 & 0.15 \\
\hline
\end{tabular}

\section{Discussion}

Some obtained results are similar to other research in which was noticed that people less frequently reserve or pay for transportation and accommodation on the Internet than search for the information (Binge et al., 2010) (Garín-Muñoz, Pérez-Amaral, 2010). Many travellers use the Internet to find information but still purchase offline.

The survey was completed mainly by young people who are enthusiasts of new technologies. They use ICT tools to find accommodation, means of transport, or another useful information for tourist, but a small percentage of them uses m-guides or audio guides. Relatively few people met described in this article innovation like electronic or smart tickets, QR codes on objects or tourist card. The reason for this may be a small number of these or the fact that the young respondents did not pay attention to these tools. Sample was not representative: young people are not always inclined to explore the monuments or sights, probably the extension of this research would give slightly different results. The second reason maybe is that, these innovations are not widely advertised. So this is an area for development. It is impossible to compare these statistics because there is no research on this area in other countries. There are researches e.g. adoption or acceptance of mobile technology (Kim at al. 2008) but without detailed questions about the purpose of their use.

Overview of urban sites showed that there is even information about the projects in which local authorities are inspired or they inspire. Respondents use the information useful for tourists, but the pages prepared by the local authorities are less common than other local pages or Google Apps. The local government should start to think more seriously about promotion and tourism. Innovative tools to assist planning tours and sightseeing will attract tourists.

\section{Conclusions}

ICT tools are changing the structure of the tourism industry. Consumer can now create own product and organise own tour without help of travel agency. There are applications helping to plan the excursion and applications like audio guides which help sightseeing. Sophisticated ICT systems allow organisations to predict and target the new consumer needs and prepare new services e.g. web pages dedicated to individual tourists or tagging monuments and facilities by 2D codes or NFC tags. It is also a challenge for the local government, which 
Joanna PAPIŃSKA-KACPEREK. E-Tourism Services in Polish Tourists' Opinions

OF MANAGE

N THE $21^{\text {st }}$ CENTURY

Volume 7, 2013

can help developing projects in support of individual tourism. It can increase of tourism in the region, and consequently bring the profit for local businesses.

The study showed that Polish tourists adopt many e-tourism solutions. They enjoy the site prepared by local authorities, but this is not the most popular source. It will be interesting to repeat a similar study in other countries and compare the results.

\section{Acknowledgements}

Acknowledgements to Dr Ewa Krok (Szczecin University) and Dr Anna Scheibe (Adam Mickiewicz University in Poznan) for inviting their students to participate in the web questionnaire.

\section{References}

Bigné, E., Sanz, S., Ruiz, C., Aldás, J. (2010). Why Some Internet Users Don’t Buy Air Tickets Online. In Information and Communication Technologies in Tourism pp. 209-221. Springer.

Buhalis, D., Law, R. (2008). Progress in information technology and tourism management: 20 years on and 10 years after the Internet - The state of eTourism research. Tourism Management, 29 (4), 609-623.

Buhalis, D., Jun, S. H. (2011). E-tourism. Goodfellow Publishers Limited, Woodeaton, Oxford.

Cech, P., Bures V., (2009). Advanced Technologies in e-Tourism, In: Proceedings of the 9th WSEAS International Conference on Applied Computer Science.

Garín-Muñoz, T., Pérez-Amaral, T. (2010). Internet Usage for Travel and Tourism. The Case of Spain, 21st European Regional ITS Conference, Copenhagen. http://hdl.handle.net/10419/44440. Retrieved 25/06/2013

Gontar, B, Papińska-Kacperek, J. (2012). E-turystyka jako element koncepcji budowania inteligentnego miasta. Zeszyty Naukowe Studia Informatica, 29, 19-30.

eTourism Case Studies. Management and Marketing Issues (2008). Egger, R., Buhalis, D. (Ed.) Elsevier.

Instytut Turystyki (2013). Krajowe i zagraniczne wyjazdy Polaków w 2012 roku http://www.msport.gov. pl/article/krajowe-i-zagraniczne-wyjazdy-polakow-w-2012-roku. Retrieved 3/06/2013.

Kim, D. Y., Park, J., Morrison, A. M. (2008). A model of traveller acceptance of mobile technology. International Journal of Tourism Research, 10 (5), 393-407.

Odkoduj Łódź (2013). About the Project http://www.odkodujlodz.pl/joomla/en\#about-project. Retrieved 25/06/2013.

Papińska-Kacperek, J. (2008). Nowa epoka - społeczeństwo informacyjne. In: Społeczeństwo informacyjne, Ed. Papińska-Kacperek J. PWN, 13-46.

Papińska-Kacperek, J. (2013). Cyfrowe usługi w transporcie, turystyce i logistyce. In: Systemy informatyczne a rozwój społeczeństwa informacyjnego Ed. Bytniewki A. Wydawnictwo UE we Wrocławiu.

Pesonen, J., Horster, E. (2012). Near field communication technology in tourism. Tourism Management Perspectives, 4, 11-18.

TNS (2013). Podróże Polaków w 2012 roku http://www.msport.gov.pl/article/podroze-polakow-w-2012roku-podstawowe-wyniki-badan Retrieved 3/06/2013.

UNWTO (2005). Understanding Tourism: Basic Glossary, World Tourism Organization http://media.unwto.org/en/content/understanding-tourism-basic-glossary. Retrieved 3/06/2013.

Advised by Ivona Orzea, Academy of Economic Studies, Bucharest, Romania

Received: April 30, 2013

Accepted: July 06, 2013

Joanna

Papińska-Kacperek
PhD., Assistant Professor, Department of Computer Science, Faculty of

Management, University of Lodz, Matejki 22/26, Lodz, Poland.

E-mail: jpapkac@pocztawz.uni.lodz.pl

Website: http://zarzadzanie.uni.lodz.pl/tabid/1709/Default.aspx?uid=28 